of a non-resistant laboratory strain and a DDT resistant strain resulted in the $F_{1}, F_{2}$ and $F_{15}$ generations having a resistance exactly intermediate between that of the parents.

My experiments on flies of Italian origin, on the other hand, give support to the theory that DDT. resistance is controlled by a single pair of allelomorphs. Crossing experiments with four pairs of flies (two reciprocal crosses) gave consistent results. The progeny of a cross was exposed to a DDT deposit of $10 \mathrm{mgm} . / \mathrm{sq}$. ft. in glass cylinders, and the time when 'knockdown' occurred in each individual fly noted; in this way the resistance of every individual in the sample was measured.

The $F_{1}$ generation of a cross between non-resistant and resistant flies had a resistance similar, although not identical, with that of a completely non-resistant strain. These hybrid flies were slightly more resistant than the non-resistant strain; but there was no fly comparable with the resistant parent.

A clear-cut segregation of non-resistant and DDT. resistant flies is apparent in the $F_{2}$ generation; the proportion of non-resistant individuals being approximately 75 per cent. The numbers of non-resistant and resistant flies in the $F_{2}$ generation of each of four crossing experiments is given in the accompanying table. Further support to this theory of singlefactor inheritance was given by a backcross between a female fly of the $F_{1}$ generation and a resistant male, when the proportion of non-resistant to resistant flies in the offspring was approximately $1: 1$.

\begin{tabular}{|c|c|c|c|c|}
\hline \multirow[b]{2}{*}{ Cross } & \multirow{2}{*}{$\begin{array}{l}\text { No. of } \\
\text { non- } \\
\text { resistant } \\
\text { flies }\end{array}$} & \multirow{2}{*}{$\begin{array}{l}\text { No. of } \\
\text { resistant } \\
\text { flies }\end{array}$} & \multirow{2}{*}{$\begin{array}{l}\text { Per cent } \\
\text { non- } \\
\text { resistart } \\
\text { flies }\end{array}$} & $\begin{array}{c}\text { Deviation } \\
\text { from } \\
\text { expected } \\
3: 1 \text { ratio }\end{array}$ \\
\hline & & & & $\begin{array}{l}\text { Standard } \\
\text { error of } \\
\text { expected } \\
\text { ratio }\end{array}$ \\
\hline $\begin{array}{l}\text { Resistant male } \times \\
\text { non-resistant female }\end{array}$ & 208 & 85 & 71 & $1 \cdot 58$ \\
\hline $\begin{array}{l}\text { Resistant male } \times \\
\text { non-resistant female }\end{array}$ & & 83 & 70 & 1.18 \\
\hline $\begin{array}{l}\text { non-resistant female } \\
\text { Non-resistant male } \times\end{array}$ & 211 & 83 & 12 & 110 \\
\hline resistant female & 75 & 22 & 77 & $1 \cdot 44$ \\
\hline resistant female & 275 & 93 & $74 \cdot 7$ & $0 \cdot 13$ \\
\hline
\end{tabular}

Many workers ${ }^{2-4}$ report a 'decline in the resistance' of DDT-resistant strains of houseflies when bred without coming into contact with DDT. Since nonresistance is dominant, the proportion of nonresistant flies in the population will increase over several successive generations provided the strain is not composed of resistant individuals only.

I wish to thank Prof. P. A. Buxton and Dr. J. R. Busvine for advice and encouragement, Dr. J. A. Fraser Roberts for helpful discussion and also the Medical Research Council for a grant supporting this work.

\section{Mary Harrison}

Entomology Department,

London School of Hygiene and Tropical Medicine,

Keppel Street,

London, W.C.1. Jan. 26.

${ }^{1}$ Bruce, W. N., and Decker, G. C., Soap, 28, 122 (1.950).

2 Barber, G. W., and Schmitt, J. B., J. Econ. Ent., 42, $278(1949)$.

${ }^{3}$ Keiding, J., and Van Deurs, H., Nature, 163,964 (1949).

'King, W. V., J. Econ. Ent., 43, 527 (1950).

\section{Heat Tolerance of Cows and Buffaloes in Egypt}

AN experiment was carried out on the College farm at Giza to study the heat tolerance of buffaloes and Egyptian, shorthorn and Jersey cows. A total of 107 females of different ages was used for a period of ten months, from November 1949 until August 1950. Body-temperature, respiration-rate and pulserate were recorded twice weekly. On each occasion six readings were taken at three-hour intervals start. ing at $6 \mathrm{a} . \mathrm{m}$. The animals were grouped according to their age and then subdivided according to their breed. The average monthly air temperature ranged from $10 \cdot 9^{\circ} \mathrm{C}$. in January to $27.8^{\circ} \mathrm{C}$. in July, and that of relative humidity from 49 per cent in May to 83 per cent in November.

The averages of body-temperature, respirationrate, and pulse-rate for the adult pure shorthorn were $38.6^{\circ} \mathrm{C}$., 17.2 and 31.9 times per 30 sec. ; for pure Jersey, $38 \cdot 2^{\circ} \mathrm{C}$., $15 \cdot 3$ and $31 \cdot 0$ times per 30 sec.; for native cows, $38 \cdot 2^{\circ} \mathrm{C}, 14.6$ and 30.7 times per 30 sec.; and for buffaloes, $38 \cdot 0^{\circ} \mathrm{C}$., $12 \cdot 2$ and $28 \cdot 0$ times per $30 \mathrm{sec}$. respectively.

The averages of body temperature and respirationrate were always higher for shorthorn cows than those of Jersey and native cows. The buffaloes had the lowest averages of body-temperature, respirationrate and pulse-rate. For all the animals studied, body-temperature, respiration-rate and pulse-rate decreased as they grew older.

The increase in air temperature caused an increase in body-temperature and respiration-rate, and a decrease in pulse-rate. The increase in the relative humidity resulted in an increase in body-temperature and pulse-rate, while it did not seem to affect respiration-rate except in the case of the shorthorns, in which it caused an increase in respiration-rate also.

The help and encouragement of Dr. H. S. Soliman Bey, dean of the College, and Dr. A. F. E. Khishin, chairman of the Animal Breeding Department, are acknowledged.

\section{A. L. BADRELDIN MoHamed M. Oloufa M. Abdel Ghany}

College of Agriculture,

Fouad University, Giza.

Jan. 11.

\section{Infectious Pneumonia of Pigs}

PNeUmonia is more common in the pig than in any other domestic animal. Usually 20-60 per cent of pigs killed in slaughter-houses in the United Kingdom and Australia have some consolidation of the lungs. In the United States and also in Great Britain, much of the pneumonia in pigs has been thought to be due to the virus of swine influenza, a virus closely related to human influenza $A$ virus. In addition to its economic importance, influenza in pigs is of interest owing to its connexion with disease in man: human strains can infect pigs naturally during epidemics in $\operatorname{man}^{1,2}$, and it has been reported that pigs may harbour the virus of swine influenza for long periods ${ }^{3,4}$. Thus pigs might serve as reservoirs for influenza viruses infectious for man.

Using accepted methods of detecting a virus of the influenza group, we have tested pneumonic lungs 